\title{
Implementasi Program Keluarga Harapan Dalam Meningkatkan Kesejahteraan Masyarakat Miskin
}

\author{
Muhammad Daud ${ }^{* 1}$, Yushita Marini ${ }^{2}$ \\ ${ }^{1}$ Administrasi, Ilmu Administrasi Negara, Universitas Terbuka UPBJJ-UT, Jl. Pendidikan, Banda \\ Aceh, 23234, Indonesia. \\ 2 Akuntansi, Ekonomi, Universitas Terbuka UPBJJ-UT, J1. Pendidikan, Banda Aceh, 23234, \\ Indonesia. \\ *Email korespondensi: mdaud@ecampus.ut.ac.id ${ }^{1}$, yushita@ecampus.ut.ac.id²
}

Diterima 14 Maret 2018; Disetujui 12 April 2018; Dipublikasi 30 April 2018

\begin{abstract}
The government has done its best to solve cases of poverty in Indonesia. However, the efforts made by the government have been implemented but the government has not been able to complete optimally and thoroughly and prosper the Indonesian people, this becomes a prolonged problem. In this case the government issued Keluarga Harapan Program (PKH). Implementation of PKH program located in Kajhu village, Baitussalam sub district, Aceh Besar district due to Rumah Tangga Sangat Miskin (RTSM) so this should get special attention from the government. The method used in this research is qualitative method with descriptive research type. The results of the research say that PKH is able to eradicate poverty in Kajhu village and able to bring prosperity to the community, so that the community is very grateful for the existence of this PKH in the village, and reduce the existing poverty. Obstacles obtained are the manipulation / forgery of data by people who are not entitled to receive PKH funds.
\end{abstract}

Keywords: implementation, $\mathrm{PKH}$, poor people

\begin{abstract}
Abstrak: Pemerintah sudah melakukan upaya semaksimal mungkin dalam menyelesaikan kasus-kasus kemiskinan yang ada di Indonesia. Namun, upaya yang dilakukan oleh pemerintah tersebut telah dilaksanakan tetapi pemerintah belum mampu menyelesaikan secara optimal dan menyeluruh serta mensejahterakan masyarakat Indonesia, ini menjadi suatu permasalahan yang berkepanjangan. Dalam hal ini pemerintah mengeluarkan Program Keluarga Harapan (PKH). Pelaksanaan program PKH yang terdapat di Desa Kajhu, Kecamatan Baitussalam, Kabupaten Aceh Besar dikarenakan adanya Rumah Tangga Sangat Miskin (RTSM) sehingga ini harus mendapatkan perhatian khusus dari pemerintah. Metode yang digunakan dalam penelitian ini adalah metode kualitatif dengan tipe penelitian analisis deskriptif. Hasil penelitian mengatakan bahwa PKH ini mampu untuk mengentaskan kemiskinan yang ada di Desa Kajhu dan mampu membawa kesejahteraan bagi masyarakat, sehingga masyarakat sangat berterimakasih atas adanya PKH ini di desa tersebut, serta mengurangi kemiskinan yang ada. Kendala yang didapatkan adalah adanya memanipulasikan/ pemalsuan data oleh masyarakat yang tidak berhak menerima dana PKH tersebut.
\end{abstract}

Kata kunci : implementasi, PKH, masyarakat miskin 
Indonesia merupakan negara kepulauan yang terdiri dari tiga puluh empat provinsi serta jumlah penduduk yang banyak. Jumlah penduduk Indonesia saat ini lebih kurang sekitar dua ratus enam puluh juta jiwa dengan profesi yang berbeda-beda. Profesi atau pekerjaan yang banyak digeluti oleh masyarakat adalah petani, buruh, supir, dan sebagainya. Berdasarkan dari upah yang diperoleh oleh setiap pekerja tersebut belum mampu untuk memenuhi kebutuhan primer bagi pekerja tersebut. Dapat dikatakan kebanyakan masyarakat Indonesia hidupnya belum sejahtera atau dengan kata lain adalah miskin.

Miskin merupakan suatu permasalahan yang harus diperhatikan serius oleh pemerintah, karena miskin dikatakan sebagai masalah social. Sehingga miskin harus ditangani dengan cepat demi mencapai suatu kesejahteraan. Kebijakan pemerintah dalam upaya penanggulangan kemiskinan telah dilakukan oleh pemerintah, dimulai dari pelayanan kesehatan, pendidikan gratis bagi masyarakat miskin, bahkan penyediaan kebutuhan panganpun sudah diberikan. Namun, hingga kini masalah kemiskinan belum bisa teratasi secara optimal, baik, dan merata bagi seluruh masyarakat Indonesia.

Soekanto (2009:321) mengatakan bahwa kemiskinan disini diartikan sebagai suatu keadaan dimana seseorang tidak sanggup memelihara dirinya sendiri sesuai dengan taraf kehidupan kelompok dan juga tidak mampu memanfaatkan tenaga mental dan juga fisiknya dalam kelompok tersebut. Selain itu, Suharto (2009:131) mengatakan bahwa kemiskinan merupakan masalah social yang senantiasa relevan untuk dikaji terus menerus. Ini bukan saja karena masalah kemiskinan telah ada sejak lama dan masih hadir di tengah-tengah kita saat ini, tetapi karena kini gejalanya semakin meningkat. Dalam hal ini, Indonesia merupakan negara berkembang dan jumlah penduduk selalu meningkat setiap tahunnya.

Menurut BAPPENAS dalam Wardan (2009:14) memberikan penjelasan tentang kemiskinan yaitu kondisi seseorang atau kelompok orang, laki-laki dan perempuan yang tidak terpenuhi hak-hak dasarnya untuk mempertahankan dan mengembangkan kehidupan yang bermartabat. Disini, peran dan upaya pemerintah sangat dibutuhkan dalam menyelesaikan permasalahan yang terjadi di masyarakat sehingga dapat mewujudkan kesejahteraan yang baik bagi masyarakat itu sendiri.

Ada dua strategi yang harus dilakukan oleh pemerintah dalam menyelesaikan kasus kemiskinan yang terus meningkat ditengah-tengah masyarakat yaitu: Pertama, melindungi keluarga dan kelompok masyarakat miskin melalui pemenuhan kebutuhan pokok mereka. Kedua, memberdayakan mereka agar mempunyai kemampuan untuk melakukan usaha dan mencegah terjadinya kemiskinan baru.

Dalam rangka menangani masalah kemiskinan yang ada di Indonesia, pemerintah mengeluarkan sebuah program yaitu Program Keluarga Harapan (PKH) yang dilaksanakan sejak tahun 2007. Menurut Dirjen Bantuan dan Jaminan Sosial (Depsos, 2010) PKH dirancang untuk membantu penduduk miskin terbawah berupa bantuan bersyarat. Program ini diharapkan mampu berkontribusi untuk mempercepat pencapaian tujuan pembangunan millennium (Millenium Development Goals atau MDGs), yaitu pengurangan penduduk miskin ekstrim dan kelaparan, pencapaian pendidikan dasar, kesetaraan gender, pengurangan angka kematian bayi dan balita, dan pengurangan 
kematian ibu melahirkan.

PKH pertama kali diimplementasikan di sejumlah negara Amerika Latin dan Karibia seperti Meksiko, Brazil, Kolombia, Honduras, Jamaica, dan Nikaragua yang dikenal dengan program Conditional Cash Transfer (CCT) atau bantuan bersyarat. Program ini berhasil menurunkan angka kemiskinan. Pada tahun 2007 pertama kali program ini dilaksanakan, ada 7 provinsi, 48 kabupaten/kota dan melayani 387.928 KSM di Indonesia dan kemudian berkembang pada tahun 2011 menjadi 25 provisni 118 kabupaten/kota dan melayani 1,1 juta KSM. Salah satunya adalah provinsi Aceh yang melaksanakan program PKH tersebut. PKH yang dilaksanakan di Aceh khususnya Desa Kajhu, Kecamatan Baitussalam, Kabupaten Aceh Besar tergolong sangat baik. Ketika dilakukan pengamatan program ini sudah dijalankan sesuai dengan mekanisme dan prosedur yang dikeluarkan oleh pihak pemerintah. Namun dalam pelaksanaannya didapati program ini tidak terlepas dari masalah/halhal yang tidak sesuai dengan program ini.

Tujuan penelitian ini adalah: Pertama, mengetahui pelaksanaan PKH di Desa Kajhu, Kecamatan Baitussalam, Kabupaten Aceh Besar. Kedua, mengetahui kendala apa saja yang terjadi dilapangan dalam pelaksanaan PKH tersebut.

\section{METODOLOGI PENELITIAN}

Metode yang digunakan dalam penelitian ini adalah metode kualitatif dengan tipe penelitian analisis deskriptif. Nazir (2006:63) mengatakan bahwa Penelitian deskriptif mempelajari masalahmasalah dalam masyarakat serta tata cara yang berlaku dalam situasi tertentu termasuk hubungan, kegiatan-kegiatan, sikap, pandangan serta proses yang berlangsung dan pengaruh dari suatu fenomena.

\section{TINJAUAN PUSTAKA}

\section{Pengertian Implementasi}

Secara etimologis, implementasi menurut kamus Webster dalam Wahab (2012:135) mengatakan bahwa istilah to implement (mengimplementasikan) itu berarti to provide the means for carrying out (menyediakan sarana untuk melaksanakan sesuatu), to give practical effect to (menimbulkan dampak/akibat terhadap sesuatu). Dalam pandangan ini implementasi diartikan sebagai proses melaksanakan keputusan kebijakan, biasanya dalam bentuk undang-undang, peraturan pemerintah, keputusan peradilan, perintah eksekutif, atau dekrit presiden.

Hinggis dalam Pasolong (2010:57) mendefinisikan implementasi sebagai rangkuman dari berbagai kegiatan yang di dalamnya sumber daya manusiamenggunakan sumber daya lain untuk mencapai sasaran strategi. Selain itu, Usman (2002:70) juga mengatakan bahwa implementasi adalah bermuara pada aktivitas, aksi, tindakan, atau adanya mekanisme suatu system. Implementasi bukan sekedar aktivitas, tetapi suatu kegiatan yang terencana dan untuk mencapai tujuan kegiatan.

Edward dalam Subarsnono (2011:90-92) mengemukakan bahwa terdapat empat variabel yang mempengaruhi kinerja impelemntasi, yakni: Pertama, Komunikasi, yaitu keberhasilan implementasi kebijakan mensyaratkan agar implementor mengetahui apa yang harus dilakukan, dimana yang menjadi tujuan dan sasaran kebijakan harus ditransmisikan kepada kelompok sasaran (target group), sehingga akan mengurangi distorsi 
implementasi. Kedua, Sumberdaya, meskipun isi kebijakan telah dikomunikasikan secara jelas dan konsisten, tetapi apabila implementor kekurangan sumberdaya untuk melaksanakan, maka impelementasi tidak akan berjalan efektif. Ketiga, Disposisi, adalah watak dan karakteristik yang dimiliki implementor, seperti komitmen, kejujuran, sifat demokratis. Keempat, Birokrasi, struktur organisasi yang bertugas mengimplementasikan kebijakan memiliki pengaruh yang signifikan terhadap implementasi kebijakan.

\section{Program Keluarga Harapan (PKH)}

Program Keluarga Harapan (PKH) merupakan program penanggulangan kemiskinan di Indonesia. PKH menanggulangi kemiskinan bagi masyarakat baik di desa maupun di kota. PKH merupakan program lintas kementerian dan lembaga, karena aktor utamanya adalah dari Badan Perencanaan Pembangunan Nasional, Departemen Sosial, Departemen Kesehatan, Departemen Pendidikan Nasional, Departemen Agama, Departemen Komunikasi dan Informatika, dan Badan Pusat Statistik. Untuk mensukseskan program tersebut, maka dibantu oleh tim tenaga ahli $\mathrm{PKH}$ dan konsultan World Bank. PKH sebenarnya telah dilaksanakan diberbagai Negara, khususnya negaranegara Amerika Latin dengan nama program yang bervariasi. Namun secara konseptual, istilah aslinya adalah Conditional Cash Transfer (CCT), yang diterjemahkan menjadi bantuan tunai bersyarat. PKH lebih dimaksudkan kepada upaya membangun sistem perlindungan sosial kepada masyarakat miskin (Modul Diklat PKH 2013).

\section{Tujuan PKH}

Tujuan utama dari PKH adalah untuk mengurangi kemiskinan dan meningkatkan kualitas sumber daya manusia terutama pada kelompok masyarakat miskin. Secara khusus tujuan khusus PKH adalah sebagai berikut: Pertama, meningkatkan kondisi sosial ekonomi RTSM. Kedua, meningkatkan taraf pendidikan anak-anak RTSM. Ketiga, meningkatkan status kesehatan dan gizi ibu hamil, ibu nifas, dan anak dibawah 6 tahun dari RTSM. Keempat, meningkatkan akses dan kualitas pelayanan pendidikan dan kesehatan, khususnya bagi RTSM, (UPPKH Pusat, Pedoman Umum PKH).

\section{Sasaran Program Keluarga Harapan}

Sasaran atau penerima bantuan PKH adalah rumah tangga sangat miskin (RTSM) yang memiliki anggota keluarga yang terdiri anak yang usia 0-15 tahun dan/atau ibu hamil/nifas dan berada pada lokasi terpilih. Penerima bantuan adalah ibu atau wanita dewasa yang mengurus anak pada rumah tangga yang bersangkutan (jika tidak ada ibu maka: nenek, tante/bibi, atau kakak perempuan dapat menjadi penerima bantuan). (Modul Diklat PKH 2013).

Calon penerima terpilih harus menandatangani persetujuan bahwa selama mereka menerima bantuan, yaitu: Pertama, menyekolahkan anak 7-15 tahun namun belum selesai pendidikan dasar 9 tahun wajib belajar. Kedua, membawa anak usia 0-6 tahun ke fasilitas kesehatan sesuai dengan prosedur kesehatan PKH bagi anak. Ketiga, untuk ibu hamil, harus memeriksakan diri dan janinnya ke fasilitas kesehatan sesuai dengan prosedur kesehatan $\mathrm{PKH}$ bagi ibu hamil. 


\section{Besaran Bantuan PKH}

Tabel 1 Besaran Bantuan Komponen PKH

\begin{tabular}{|l|l|r|}
\hline No & \multicolumn{1}{|c|}{ Komponen Bantuan } & $\begin{array}{c}\text { Indeks } \\
\text { Bantuan (Rp) }\end{array}$ \\
\hline 1 & Bantuan ibu hamil/menyusui & 1.200 .000 \\
\hline 2 & $\begin{array}{l}\text { Bantuan anak usia dibawah 6 } \\
\text { tahun }\end{array}$ & 1.200 .000 \\
\hline 3 & $\begin{array}{l}\text { Bantuan peserta pendidikan setara } \\
\text { SD/Sederajat }\end{array}$ & 450.000 \\
\hline 4 & $\begin{array}{l}\text { Bantuan peserta pendidikan setara } \\
\text { SMP/Sederajat }\end{array}$ & 750.000 \\
\hline 5 & $\begin{array}{l}\text { Bantuan peserta pendidikan setara } \\
\text { SMA/Sederajat }\end{array}$ & 1.000 .000 \\
\hline 6 & $\begin{array}{l}\text { Bantuan penyandang disabilitas } \\
\text { berat }\end{array}$ & 3.100 .000 \\
\hline 7 & $\begin{array}{l}\text { Bantuan lanjut usia 70 tahun } \\
\text { keatas }\end{array}$ \\
\hline
\end{tabular}

\section{Mekanisme Pelaksanaan PKH}

Proses utama dalam pelaksanaan PKH yang kemudian dijelaskan secara lebih rinci sebagai berikut: (1) penyediaan data calon peserta $\mathrm{PKH}$ (mulai tahun 2012 bersumber dari Basis Data Terpadu/berdasarkan data dari BPS). (2) penetapan lokasi dan penentuan calon peserta PKH (Penetapan Sasaran). (3) pengecekan keabsahan, kebenaran, dan perubahan data calon peserta PKH (Validasi). (4) pembayaran dana tunai yang terdiri dari (a) pembayaran pertama setelah validasi bagi peserta baru dilakukan, (b) pembayaran selanjutnya berdasarkan hasil verifikasi bagi peserta lainnya. (5) verifikasi kepatuhan kewajiban. (6) pemutakhiran data.

\section{Kesejahteraan Masyarakat}

\section{Pengertian Kesejahteraan Masyarakat}

\section{Secara Umum}

Badrudin (2012:146) mengatakan bahwa kesejahteraan masyarakat adalah suatu kondisi yang memperlihatkan tentang keadaan kehidupan masyarakat yang dapat dilihat dari standar kehidupan masyarakat tersebut. Selain itu, Abbas (2008:126) juga mengungkapkan bahwa kesejahteraan dapat diartikan sebagai kecukupan pemenuhan kebutuhan, orang yang merasa sejahtera apabila ia merasa senang, tidak kurang suatu apapun dalam batas yang mungkin dicapainya, jiwanya tentram dan batinnya terpelihara, ia merasa keadilan ada dalam hidupnya, ia terlepas dari kemiskinan yang menyiksa dan terhindar dari bahaya kemiskinan yang mengancam.

Pengertian kesejahteraan berdasarkan UndangUndang Republik Indonesia Nomor 11 Tahun 2009 tentang Kesejahteraan Sosial Pasal 1 ayat (1): "Kesejahteraan sosial adalah kondisi terpenuhinya kebutuhan material, spiritual, dan sosial warga Negara agar dapat hidup layak dan mampu mengembangkan diri, sehingga mampu melaksanakan fungsi sosialnya.

\section{Indikator Kesejahteraan Masyarakat}

Badrudin (2010:148) mengungkapkan bahwa kesejahteraan masyarakat dapat diukur dengan beberapa indikator-indikator kesejahteraan yang merupakan suatu ukuran ketercapaian masyarakat dimana masyarakat dapat dikatakan sejahtera atau tidak. Beberapa indikator kesejahteraan masyarakat menurut beberapa instansi pemerintah, antara lain sebagai berikut: Pertama, menurut Bappenas, status kesejahteraan dapat diukur berdasarkan proporsi pengeluaran rumah tangga. Rumah tangga dapat dikategorikan sejahtera apabila proporsi pengeluaran kebutuhan pokok sebanding atau lebih rendah dari proporsi pengeluaran untuk kebutuhan bukan pokok.

Kedua, kriteria untuk menentukan atau rumah tangga miskin seperti: (a) luas bangunan peranggota rumah tangga/keluarga kurang dari 8 meter persegi; (b) lantai rumah berupa tanah/papan dengan kualitas rendah; (c) dinding rumah berupa bamboo/papan 
dengan kualitas rendah; (d) fasilitas MCK belum tersedia; (e) sumber air minum bukan air bersih; (f) sumber penerangan yang digunakan bukan listrik; (g) jenis bahan bakar untuk memasak adalah kayu; (h) frekuensi makan dalam sehari kurang dari dua kali; (i) tidak mampu membeli daging /susu/ayam dalam seminggu.

\section{Pengertian Kemiskinan}

Kuncoro (2002:112) mengatakan bahwa kemiskinan adalah suatu kondisi ketidakmampuan secara ekonomi dalam memenuhi standar kebutuhan dasar rata-ratapada suatu daerah. Kondisi ketidakmampuan ini ditandai dengan rendahnya kemampuan pendapatan untuk memenuhi kebutuhan pokok baik berupa pangan, sandang, maupun papan. Selanjutnya, Suryawati (2005:112) juga mengatakan bahwa kemampuan pendapatan yang rendah bukan saja berakibat pada tidak tercukupinya kebutuhan dasar akan tetapi berdampak pada ketidakmampuan memenuhi standar hidup rata-rata seperti standar kesehatan masyarakat dan standar pendidikan.

Ratih (2007:185) mengatakan bahwa kemiskinan merupakan istilah yang menyatakan tidak adanya kenikmatan hidup dan persediaan kebutuhanpun tidak sebanding. Istilah ini didefinisikan sebagai suatu titik kehilangan untuk pemeliharaan efisensi secara fisik. Atau suatu keadaan ekonomi dimana terbatasnya peluang atau kesempatan yang dimiliki kelompok tersebut dalam mengakses sumber daya pembangunan (Basri, 2005:98-99).

\section{Bentuk dan Jenis Kemiskinan}

Sthepan (2003:247) mengatakan bahwa kemiskinan memiliki 4 bentuk yaitu: Pertama,
Kemiskinan Absolut, adalah suatu kondisi dimana pendapatan seseorang atau sekelompok orang berada dibawah garis kemiskinan, sehingga kurang mencukupi untuk memenuhi kebutuhan standar untuk pangan, sandang, kesehatan, perumahan, pendidikan yang diperlukan untuk meningkatkan kualitas hidup. Kedua, Kemiskinan Relatif, diartikan sebagai bentuk kemiskinan yang terjadi karena adanya pengaruh kebijakan pembangunan yang belum menjangkau keseluruh lapisan masyarakat sehingga menyebabkan adanya ketimpangan pendapatan atau ketimpangan standar kesejahteraan.

Ketiga, Kemiskinan Kultural, kemiskinan yang mengacu pada sikap, gaya hidup, nilai, orientasi sosial budaya seseorang atau masyarakat yang tidak sejalan dengan etos kemajuan masyarakat modern. Keempat, Kemiskinan Struktural, adalah kemiskinan yang disebabkan karena rendahnya akses terhadap sumberdaya pada umumnya terjadi pada suatu tatanan sosial budaya ataupun sosial politik yang kurang mendukung adanya pembebasan kemiskinan.

Jenis kemiskinan sebagai berikut: (1) Kemiskinan Alamiah, adalah kemiskinan yang terbentuk sebagai akibat adanya kelangkaan sumber daya alam dan minimnya sarana umum (jalan raya, listrik, air bersih). Umumnya kondisi ini dialami oleh daerah yang belum terjangkau oleh pembangunan sehingga menjadi daerah tertinggal. (2) Kemiskinan Buatan, adalah kemiskinan yang diakibatkan oleh system modernisasi atau kemiskinan yang membuat masyarakat sulit untuk menguasai sumber daya alam, sarana umum, dan fasilitas ekonomi secara merata. 


\section{Program Mengentaskan Kemiskinan}

TNP2K dalam Kartiawati

(2017:33) mengatakan bahwa untuk meningkatkan efektifitas dalam upaya penanggulangan kemiskinan presiden telah mengeluarkan Perpres No.15 Tahun 2010 tentang Penanggulangan Kemiskinan, yang bertujuan untuk mempercepat penurunan angka kemiskinan hingga $8 \%$ sampai $10 \%$ pada akhir tahun 2014. Melalui Tim Nasional Percepatan Penanggulangan Kemiskinan (TNP2K) dibawah koordinasi Wakil Presiden Republik Indonesia, telah mengklasifikasikan kebijakan dalam tiga kelompok (cluster) yaitu sebagai berikut:

Pertama, klaster I, adalah kelompok kebijakan penanggulangan kemiskinan berbaris bantuan dan perlindungan sosial. Focus utama kebijakan ini adalah untuk pemenuhan hak dasar yang ditujukan untuk memperbaiki kualitas kehidupan masyarakat miskin untuk kehidupan masyarakat miskin untuk kehidupan yang lebih baik. Mekanisme pelaksanaan program bersifat langsung dan klasifikasi program ini meliputi program Jaminan Kesehatan Masyarakat (JAMKESMAS), Beras untuk Keluarga Miskin (RASKIN), Bantuan Siswa Miskin (BSM), dan Program Keluarga Harapan (PKH).

Kedua, klaster II, adalah kelompok kebijakan berbasis pemberdayaan masyarakat. Focus utama program ini adalah untuk memperbaiki kualitas kehidupan masyarakat miskin melalui pendekatan pemberdayaan yang dimaksdukan agar masyarakat keluar dari kemiskinan dengan menggunakan potensi dan sumberdaya yang dimiliki. Jenis program klaster II ini adalah PNPM Mandiri.

Ketiga, Klaster III, adalah kebijakan berbasis pemberdayaan usaha mikro yang memberikan akses seluas-luasnya kepada masyarakat miskin untuk

dapat berusaha dan meningkatkan kualitas hidupnya dengan memberikan modal atau pembiayaan dalam skala mikro. Program pada klaster III ini adalah Kredit Usaha Rakyat (KUR).

\section{HASIL DAN PEMBAHASAN}

Pelaksanaan PKH di Desa Kajhu, Kecamatan

\section{Baitussalam, Kabupaten Aceh Besar}

Program Keluarga Harapan (PKH) merupakan program yang dikeluarkan oleh pemerintah untuk menyelesaikan dan menuntaskan kemiskinan di Indonesia. PKH ini salah satu solusi yang diberikan oleh pemerintah untuk mengatasi kemiskinan. Dalam hal ini, program mengentaskan kemiskinan. PKH memberikan dana tunai langsung kepada masyarakat miskin yang berkategori keluarga sangat miskin. Untuk mendapatkan dana tunai langsung tersebut dari pemerintah, tentunya ada syarat-syarat yang harus dipenuhi oleh penerima dana tersebut.

Hasil penelitian yang penulis temukan dilapangan yang menjadi penentu pelaksanaan $\mathrm{PKH}$ di Desa Kajhu, Kecamatan Baitussalam Kabupaten Aceh Besar adalah tentunya langkah-langkah persiapan pelaksanaan terlebih dahulu agar tujuan yang ingin diharapkan tercapai dengan maksimal. Pelaksanaan PKH ini dimulai dari pemilihan kabupaten/kota oleh Badan Pusat Statisti (BPS), penentuan lokasi penerima $\mathrm{PKH}$, pemilihan pendamping, dan menentukan peserta PKH. Selanjutnya, untuk mengumpulkan data yang valid selama dilapangan harus adanya kerjasama antara satuan kerja terkait. Tujuan apa yang diharapkan dapat terlaksana dengan baik.

Pelaksanaan PKH di Desa Kajhu ini para pendamping harus melakukan dan membuat strategi 
dan sosialisasi kepada masyarakat, karena banyaknya masyarakat Desa Kajhu yang masih awam terhadap program ini. Sehingga para pendamping harus kerja secara maksimal, dalam hal ini pendamping setiap harinya harus mengunjungi rumah tangga sangat miskin yang terdapat di Desa Kajhu, serta memantau kebutuhan sekolah maupun kondisi ibu-ibu yang sedang hamil peserta $\mathrm{PKH}$. Penggunaan dana yang dikeluarkan setiap peserta PKH ini harus dipantau dengan tujuan jangan sampai disalahgunakan oleh peserta PKH. Dalam mensukseskan program ini PKH dapat melaksanakan tugas dengan baik dilapangan. Sosialisasi yang diberikan oleh pendamping PKH dilakukan disalah satu rumah peserta dengan cara bergilir demi terjalinnya silaturahmi dengan baik antara peserta yang satu dengan yang lainnya.

Yang menjadi sasaran utama dalam pelaksanaan PKH di Desa Kajhu ini adalah rumah tangga sangat miskin, sesuai dengan mana yang telah disepakati yaitu ibu yang sedang hamil, ibu menyusui, memiliki balita, dan anak usia sekolah setingkat SD/MI dan SMP/MTs. Berdasarkan peraturan perundang-undangan $\mathrm{PKH}$ dijalankan dijalankan sebagai pelaksanaan dari UU No.40 tahun 2004 tentang jaminan sosial nasional, UU No.11 tahun 2009 tentang kesejahteraan sosial, Inpres No.3 tahun 2010 tentang Rencana Tindak Percepatan Pencapaian Sasaran Program ProRakyat, Perpres No.15 tahun 2010 tentang Percepatan Penanggulangan Kemiskinan. Merujuk pada system jaminan sosial nasional berdasarkan UU. No.40 tahun 2004 tersebut. PKH merupakan jaminan yang pro rakyat miskin, dimaksudkan untuk mempertahankan kehidupan dalam pemenuhan kebutuhan dasar terutama pendidikan dan kesehatan.
Desa Kajhu sebagai salah satu desa yang menjalankan program ini memberikan bantuan tersebut sesuai dengan peraturan yang berlaku yang dikeluarkan oleh pemerintah. Bantuan tersebut adil dan merata kepada peserta rumah tangga sangat miskin. Program PKH ini memberikan bukti yang sangat nyata bagi masyarakat Indonesia khususnya bagi peserta penerima program PKH. Artinya, program ini sudah betul-betul terealisasi didalam masyarakat, hal ini sudah nampak perubahan dari sebelum menerima bantuan hingga setelah menerima bantuan tersebut. Adanya anggapan bahwa apabila dana tersebut tidak digunakan sebagaimana semestinya maka pendamping akan memberikan sanksi yang tegas kepada para peserta PKH tersebut atau bisa dibatalkan sebagai peserta penerima program $\mathrm{PKH}$.

Oleh karenanya, pelaksanaan PKH di Desa Kajhu ini diseleksi secara ketat dan betul-betul memperhatikan siapa saja yang berhak menerima dan menggunakan dana tersebut dengan baik. Hal ini Desa Kajhu dikenal sebagai desa yang melaksanakan dan menjalankan PKH dengan baik. Memberikan sanksi bagi peserta yang melanggar dan tidak taat pada aturan berlaku sanksi yang sangat tegas dari pendamping, suapaya mendapatkan efek jera bagi pendamping tersebut.

Hasil penelitian yang ditemukan dilapangan, program ini telah membantu masyarakat khususnya bagi peserta penerima PKH. Dengan kata lain, Desa Kajhu sudah memberikan hasil yang baik bagi rumah tangga sangat miskin. Hal ini mampu mengurangi angka kemiskinan di Desa Kajhu, dan terutama aspek kesehatan dan pendidikan. Sehingga anak yang hamper putus sekolahpun bisa melanjutkan pendidikan dengan baik. Tujuan utama 
dari program ini untuk mengentaskan kemiskinan dapat berkurang di provinsi Aceh, khususnya di Desa Kajhu, Kecamatan Baitussalam, Kabupaten Aceh Besar.

\section{Kendala PKH di Desa Kajhu Kecamatan}

\section{Baitussalam Kabupaten Aceh Besar}

Di Desa Kajhu yang menjadi kendala dalam melaksanakan program ini adalah kurang mengertinya rumah tangga sangat miskin terhadap sanksi yang diberikan akibat pelanggaran yang dilakukan oleh peserta PKH. Hal ini dikarenakan adanya penggunaan kartu PKH yang tidak sesuai digunakan. Sehingga ketika melakukan pencairan peserta PKH mengalami kesulitan pada pencairan dana.

Kendala lain dalam pelaksanaan program ini adalah adanya data yang tidak benar yang dilakukan oleh masyarakat yang mengaku menjadi orang miskin untuk mendapatkan dana PKH tersebut. Ini dikarenakan terjadinya pemalsuan data yang dilakukan saat verifikasi di Desa Kajhu.

\section{KESIMPULAN DAN SARAN}

\section{Kesimpulan}

Berdasarkan hasil penelitian dilapangan, peneliti dapat menyimpulkan bahwa:

(1) Dengan adanya Program Keluarga Harapan $(\mathrm{PKH})$ ini maka masyarakat dapat diberikan bantuan seperti kesejahteraan;

(2) Kesehatan ibu hamil, menyusui, dan balita perlu mendapat perhatian khusus;

(3) Kemiskinan bisa berkurang dengan adanya PKH;

(4) Pemerintah harus meneruskan program ini demi mewujudkan suatu kesejahteraan bagi masyarakat Indonesia.

\section{DAFTAR PUSTAKA}

Abbas, Anwar. (2008). Bunghatta dan Ekonomi Islam. Jakarta: Multi Press Indo.

Badrudin, Rudy. (2010). Ekonomi Otonomi Daerah. Yogyakarta: UPP STIM YKPM

Basri, Faisal. (2005). Perekonomian Indonesia. Jakarta: Erlangga

Kartiawati. (2017). Analisis Efektifitas Program Keluarga Harapan (PKH) Dalam Pengentasan Kemiskinan Ditinjau Dari Perspektif Ekonomi Islam. Lampung: Fakultas Ekonomi dan Bisnis IslamInstitut Agama Islam Negeri Raden Intan

Kuncoro, Mudrajad. (2002). Ekonomika Pembangunan, Teori, Masalah, dan Kebijakan. Yogyakarta: YKPN

Nazir, Muhammad. (2000). Metode Penelitian. Jakarta: Rineka Cipta

Pasolong, Harbani. (2010). Teori Administrasi Publik. Bandung: Alfabeta

Pedoman Umum Pelaksanaan Program Keluarga Harapan (PKH) Tahun 2008. Jakarta: Kementerian Sosial RI

Ratih, T. Rochaety, Eti. (2007). Kamus Istilah Ekonomi. Jakarta: Bumi Aksara

Soekanto, Soerjono. (2009). Sosiologi Suatu Pengantar. Jakarta: Rajawali Pers

Stephan, C.Smith. Michael, P. Torado. (2003). Pembangunan Ekonomi di Dunia Ketiga: Edisi Kedelapan. Jakarta: Erlangga

Subarsono, A.G. (2011). Analisis Kebijakan Publik: Konsep, Teori dan Aplikasi. Yogyakarta: Pustaka Belajar

Suryawati, Chriswardani. (2005). Memahami Kemiskinan Secara Multidimensional. Jurnal Manajemen Pelayanan Kesehatan, 
Jurnal Humaniora, Vol.2, No. 1, April 2018 : 29-38

http://jurnal.abulyatama.ac.id/humaniora

Vol. 08/No.03/September.

Usman, Nurdin. (2002). Konteks Implementasi

Berbasis Kurikulum. Yogyakarta: Bintang

Pustaka

Wardan, Anang Solihin. (2009). Peduli

Kemiskinan. Bandung: Remaja

Rosdakarya

Wahab, Soloichin. A. (2004). Analisa Kebijakan

dari Formulasi ke Implementasi

Kebijaksanaan Negara. Malang: Bumi

Aksara

- How to cite this paper :

Daud, M., \& Marini, Y. (2018). Implementasi

Program Keluarga Harapan Dalam

Meningkatkan Kesejahteraan Masyarakat

Miskin. Jurnal Humaniora, 2(1), 29-38. 